\title{
RANCANGAN \\ SISTEM PENGOLAHAN DATA TAMU
}

\author{
DIKA SAPUTRA \\ 165100045, 785567952 \\ Fakultas Komputer \\ Dikakotek12@gmail.com
}

\begin{abstract}
Saat ini, perkembangan teknologi informasi berkembang lebih pesat. Tidak heran banyak perusahaan sekarang mulai mengembangkan sistem administrasi menggunakan teknologi informasi, salah satunya adalah perusahaan di bidang perhotelan. Masih memproses data secara manual dapat memperlambat kinerja karyawan dan layanan untuk tamu hotel.

Pemrosesan data di sebuah hotel atau rumah tamu harus memiliki sistem pemrosesan data yang baik dan teratur, yang akan berguna untuk kelancaran penyimpanan data dan dapat memberikan keamanan data. Dengan sistem pemrosesan data untuk memberikan kenyamanan bagi para tamu setiap pemilik hotel dan wisma untuk memberikan layanan maksimal bagi para tamu yang menginap.

Giating Hotel adalah salah satu wisma terkenal di antara para wisatawan di Indonesia domestik dan luar negeri. Lokasinya yang strategis di Tanggamus membuat Giating Hotel diminati oleh para wisatawan. Untuk memberikan layanan yang memuaskan bagi para tamunya, perlu ada beberapa perbaikan sistem seperti sistem pemesanan sewa kamar, sistem check-in, sistem check-out dan sistem lainnya.
\end{abstract}

Kata Kunci : pengolahan data, hotel.

\section{A. INTRODUCTION}

Saat ini, perkembangan teknologi informasi berkembang lebih pesat. Tidak heran banyak perusahaan sekarang mulai mengembangkan sistem administrasi menggunakan teknologi informasi, salah satunya adalah perusahaan di 
bidang perhotelan. Masih memproses data secara manual dapat memperlambat kinerja karyawan dan layanan untuk tamu hotel.

\section{B. CONTENT}

Pemrosesan data di sebuah hotel atau rumah tamu harus memiliki sistem pemrosesan data yang baik dan teratur, yang akan berguna untuk kelancaran penyimpanan data dan dapat memberikan keamanan data. Dengan sistem pemrosesan data untuk memberikan kenyamanan bagi para tamu setiap pemilik hotel dan wisma untuk memberikan layanan maksimal bagi para tamu yang menginap.

\section{CONCLUSION}

Giating Hotel adalah salah satu wisma terkenal di antara para wisatawan di Indonesia

domestik dan luar negeri. Lokasinya yang strategis di Tanggamus membuat Giating Hotel diminati oleh para wisatawan. Untuk memberikan layanan yang memuaskan bagi para tamunya, perlu ada beberapa perbaikan sistem seperti sistem pemesanan sewa kamar, sistem check-in, sistem check-out dan sistem lainnya.

\section{DISCUSSION}

Untuk memberikan layanan yang memuaskan bagi para tamunya, perlu ada beberapa perbaikan sistem seperti sistem pemesanan sewa kamar, sistem check-in, sistem check-out dan sistem lainnya. 


\section{E. REFERENCE}

[1] O. M. Febriani and A. S. Putra, "Sistem Informasi Monitoring Inventori Barang Pada Balai Riset Standardisasi Industri Bandar Lampung," J. Inform., vol. 13, no. 1, pp. 90-98, 2014.

[2] A. S. Putra, "Paperplain: Execution Fundamental Create Application With Borland Delphi 7.0 University Of Mitra Indonesia," 2018.

[3] A. S. Putra, "2018 Artikel Struktur Data, Audit Dan Jaringan Komputer," 2018.

[4] A. S. Putra, "ALIAS MANAGER USED IN DATABASE DESKTOP STUDI CASE DB DEMOS."

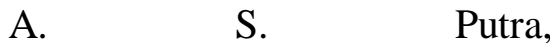
"COMPREHENSIVE SET OF PROFESSIONAL FOR DISTRIBUTE COMPUTING."

[6] A. S. Putra, "DATA ORIENTED RECOGNITION IN BORLAND DELPHI 7.0."

[7] A. S. Putra, "EMBARCADERO
DELPHI XE 2 IN GPUPOWERED FIREMONKEY APPLICATION."

[8] A. S. Putra, "HAK ATAS KEKAYAAN INTELEKTUAL DALAM DUNIA TEKNOLOGY BERBASIS REVOLUSI INDUSTRI 4.0."

[9] A. S. Putra, "IMPLEMENTASI PERATURAN PERUNDANGAN UU. NO 31 TAHUN 2000 TENTANG DESAIN INDUSTRI BERBASIS INFORMATION TECHNOLOGY."

[10] A. S. Putra, "IMPLEMENTATION OF PARADOX DBASE."

[11] A. S. Putra, "IMPLEMENTATION OF TRADE SECRET CASE STUDY SAMSUNG MOBILE PHONE."

A. S. Putra, "IMPLEMENTATION

PATENT FOR APPLICATION WEB BASED CASE STUDI WWW. PUBLIKLAMPUNG. COM."

[13] A

"IMPLEMENTATION

SYSTEM FIRST TO INVENT IN DIGITALLY INDUSTRY."

[14] A. S. Putra, "MANUAL REPORT \& INTEGRATED DEVELOPMENT

ENVIRONMENT BORLAND DELPHI 7.0."

[15] A. S. Putra, "PATENT AS RELEVAN SUPPORT RESEARCH."

[16] A. S. Putra, "PATENT FOR RESEARCH STUDY CASE OF APPLE. Inc."

[17] A. S. Putra, "PATENT 
PROTECTION

FOR

APPLICATION INVENT."

A. S. Putra, "QUICK REPORT

IN PROPERTY

PROGRAMMING."

[19] A. S. Putra, "REVIEW CIRCUIT LAYOUT COMPONENT

REQUIREMENT ON ASUS NOTEBOOK."

[20] A. S. Putra, "REVIEW TRADEMARK PATENT FOR INDUSTRIAL TECHNOLOGY BASED 4.0."

[21] A. S. Putra, "TOOLBAR COMPONENT PALLETTE IN OBJECT ORIENTED PROGRAMMING."

[22] A. S. Putra, "WORKING DIRECTORY SET FOR PARADOX 7."

[23] A. S. Putra, "ZQUERY CONNECTION

IMPLEMENTED

PROGRAMMING

STUDI

CASE PT. BANK BCA Tbk."

[24] A. S. Putra, D. R. Aryanti, and I. Hartati, "Metode SAW (Simple Additive Weighting) sebagai Sistem Pendukung Keputusan Guru Berprestasi (Studi Kasus: SMK Global Surya)," in Prosiding Seminar Nasional Darmajaya, 2018, vol. 1, no. 1, pp. 85-97.

[25] A. S. Putra and O. M. Febriani, "Knowledge Management Online Application in PDAM Lampung Province," in Prosiding International conference on Information Technology and Business (ICITB), 2018, pp. 181-187.

[26] A. S. Putra, O. M. Febriani, and B. Bachry, "Implementasi
Genetic Fuzzy System Untuk Mengidentifikasi Hasil Curian Kendaraan Bermotor Di Polda Lampung," SIMADA (Jurnal Sist. Inf. dan Manaj. Basis Data), vol. 1, no. 1, pp. 21-30, 2018.

[27] A. S. Putra, H. Sukri, and K. Zuhri, "Sistem Monitoring Realtime Jaringan Irigasi Desa (JIDES) Dengan Konsep Jaringan Sensor Nirkabel," IJEIS (Indonesian J. Electron. Instrum. Syst., vol. 8, no. 2, pp. 221-232.

[28] D. P. Sari, O. M. Febriani, and A. S. Putra, "Perancangan Sistem Informasi SDM Berprestasi pada SD Global Surya," in Prosiding Seminar Nasional Darmajaya, 2018, vol. 1, no. 1, pp. 289-294. 